\title{
Vitamin D as an important constituent of epididymal luminal micro-environment for maturation of spermatozoa in Large White Yorkshire boar
}

\author{
Somraj Chattaraj ${ }^{1}$, Siddhartha Basu ${ }^{1 *}$, Kalyani Ray ${ }^{1}$, and Dhiman S. Pal ${ }^{2}$ \\ ${ }^{1}$ Department of Veterinary Gynaecology and Obstetrics, Faculty of Veterinary and Animal Sciences, \\ West Bengal University of Animal and Fishery Sciences, Kolkata, WB, India \\ ${ }^{2}$ Department of Biological Sciences, Indian Institute of Science Education and Research (IISER) Kolkata, \\ Mohonpur, WB, India
}

CHATTARAJ, S., S. BASU, K. RAY, D. S. PAL: Vitamin D as an important constituent of epididymal luminal micro-environment for maturation of spermatozoa in Large White Yorkshire boar. Vet. arhiv 89, 169-182, 2019.

\section{ABSTRACT}

Vitamin-D (VD) is known to modulate reproductive processes through the expression of VDR in the male reproductive tract. To understand its influence in the initiation of sperm motility in epididymis, VD concentration was measured in serum, epididymal luminal fluid (ELF) and sperm cytosolic fluid (SCF) from the caput, corpus and cauda epididymis of Large White Yorkshire (LWY) boars $(n=30)$ of around 3-4 years of age. The relationship of VD concentration with sperm motility in epididymal segments was then observed. A progressive increase in sperm motility from caput to cauda epididymis was found with highest in cauda followed by corpus. Motility was found absent in the caput region. VD levels in serum were positively correlated with spermatozoan motility from the corpus $(\mathrm{r}=0.819)$ and cauda $(\mathrm{r}=0.961)$, and this was highly significant $(\mathrm{P}<0.01)$. Again, ELF and SCF VD levels exhibited a positive correlation with that of sperm motility in the corpus and cauda in the respective segments of the epididymis, and this was highly significant $(\mathrm{P}<0.01)$. Semi-quantitative RT-PCR revealed VDR gene expression in epididymal segments and in sperm from the cauda epididymis in an LWY boar. The increase in amounts of VDR transcript (non-significant at $\mathrm{P}>0.05$ ) from sections of caput to cauda epididymis was in concurrence with the increasing concentration of VD from the caput to cauda epididymis suggesting the influence of VD in the initiation of sperm motility in the excurrent duct. VD levels in serum may also pave the way for the development of specific marker(s) to assist in the prediction and early diagnosis of idiopathic infertility in males due to epididymal dysfunction resulting from VD deficiency. This will help clinically in improving treatment modalities of this idiopathic male infertility.

Key words: Vitamin-D; epididymal luminal fluid; sperm cytosolic fluid; sperm motility; Semi-quantitative RT-PCR; VDR gene

\footnotetext{
*Corresponding author:

Prof. Dr. Siddhartha Basu, Department of Veterinary Gynaecology and Obstetrics, Faculty of Veterinary and Animal Sciences, West Bengal University of Animal and Fishery Sciences, Kolkata-700 037, WB, India, Phone: +91 332585 6973/ +91943 317 5052; E-mail: drsbasu_61@rediffmail.com
}

ISSN $0372-5480$

Printed in Croatia 
S. Chattaraj et al.: Vitamin D as an important constituent of epididymal luminal micro-environment for maturation of spermatozoa in Large White Yorkshire Boar

\section{Introduction}

Spermatozoa produced by the testes are initially morphologically complete yet non-functional. They acquire their physiological functions, such as the possibility of motility and fertilizing ability as they traverse through the epididymis (DACHEUX and PAQUIGNON 1980; ROBAIRE et al., 2006). It is the most sequentially modified epididymal luminal fluid that brings out the morphological and biochemical changes on the surface of the sperm. This is essential in the process of sperm maturation. In this process, various bio-molecules, such as enzymes, proteins, lipids, glycoproteins, hormones and vitamins are secreted into the luminal fluid from the different regions of the epididymis. The epididymis provides a specialized milieu where the sperm plasma membrane is modified through interaction with luminal proteins and lipids (DACHEUX and DACHEUX, 2013).

Among the many important characteristics of the luminal micro-environment/ secretion of the individual epididymal segments, the role of 1,25-dihydroxyvitamin D3 [1,25-(OH)2 D3] (VD) in the induction of sperm motility of LWY boars has been examined in this present study. This area was chosen since hardly any work has been done on this species in the field of male reproduction, whether in our country or abroad. Besides, pigs provide a good model for biomedical research on humans, as pigs and humans show many similarities in physiological, biochemical etc. aspects (WERNERSSON et al., 2005 ) since the evolutionary distance between the porcine and human genomes is smaller than that of the mouse and humans.

Besides, considering the fact that the males play an important role in animal reproduction and their infertility may affect the entire management practice of a herd, early detection and treatment of male infertility is very essential. However, we are only capable of diagnosing and treating male infertility of an infectious nature, otherwise a valuable animal is culled. On the other hand, idiopathic causes of infertility, that are reflected in sperm maturational disorders, are most common in the case of male infertility (SULLIVAN, 2004; CORNWALL, 2009) and they often go undiagnosed. Therefore, if we can find a relationship between the biochemical constituents of the serum and those of the ELF and SCF, the serum levels of these biochemical constituents may serve as markers. In that case, any deviation in values from the standard range may help us diagnose male infertility. As we can then be certain of the reasons for it, quick and appropriate treatment may be administered.

Therefore, in order to understand the influence of VD in the initiation of sperm motility in the epididymis, and for the early diagnosis of idiopathic causes of infertility, the present study aimed at finding the relationship between sperm motility in the epididymis with respect to the levels of VD in the serum and in ELF and SCF taken from different epididymal segments. Further, for the first time, the expression was studied of the VDR gene in the reproductive tissues/cells, viz. epididymal tissues, from the caput, corpus and 
S. Chattaraj et al.: Vitamin D as an important constituent of epididymal luminal micro-environment for maturation of spermatozoa in Large White Yorkshire Boar

cauda epididymis, and spermatozoa taken from the cauda epididymis of LWY boars, by the semi-quantitative Polymerase Chain Reaction (PCR). Their expression levels in the tissues were compared in order to ascertain the influence of VD in male reproduction, especially in the process of maturation of spermatozoa in the epididymis.

\section{Materials and methods}

Blood samples from each of 30 (thirty) healthy LWY boars, proven to be reproductively mature at around 3-4 years of age, were collected from the ear vein on the same day before their slaughter. Then the serum was separated, aliquoted, labelled and kept at -20 ${ }^{\circ} \mathrm{C}$ until experimentation.

Collection and processing of the epididymis. The testes, along with the epididymis were collected as slaughter house material (waste) during slaughter from the same selected (30) pigs and transferred to sterile containers. Both the epididymes from the testis-epididymis complex were separated, their three segments, viz. the caput, corpus, and cauda of each, were ligated separately and dissected. Immediately after slaughter, tissue samples (approx. 50-100 mg) from one side of the epididymal caput, corpus and cauda, and epididymal fluid from the cauda containing mature spermatozoa, were transferred to labelled tubes containing $1 \mathrm{mLof}$ Trizol (Invitrogen, USA) for studying the VDR gene expression. Further, dissected parts were properly labelled and stored in containers with ice-cold $0.15 \mathrm{M}$ phosphate buffered saline (PBS, pH 7.4) at $5{ }^{\circ} \mathrm{C}$ in a refrigerator until processed.

Salvaging of ELF and separation of SCF. Epididymal fluids containing the spermatozoa from each segment of both the right and left epididymes were obtained by mincing the epididymes (FRENETTE et al., 2002; HORI et al., 2015). The ELF from each segment of the left epididymis was used to assess the spermatozoan motility (ANONYM, 1997) whereas the ELF salvaged from each segment of the right epididymis was centrifuged at $4{ }^{\circ} \mathrm{C}$ at $700 \mathrm{~g}$ for $5 \mathrm{~min}$ to remove the spermatozoa (FRENETTEET. al., 2002). Then the supernatant was again centrifuged at $4{ }^{\circ} \mathrm{C}$ at $18,000 \mathrm{~g}$ for $20 \mathrm{~min}$ in order to remove the remaining cellular debris (WALES et al., 1966). The ELF was then stored in properly labelled micro-centrifuge tubes. The spermatozoa thus separated were then sonicated using an ultrasonicator (Sonics, Vibra-Cell, USA) to separate the SCF from it (VIJAYARAGHAVAN et al.,1996). The sonicated materials were then centrifuged at $4{ }^{\circ} \mathrm{C}$ at $16,000 \mathrm{~g}$ for $10 \mathrm{~min}$ (VIJAYARAGHAVAN et al., 1996) and supernatant containing the total cell lysate were separated and filtered using a membrane filter. SCF was carefully aliquoted in properly labelled micro-centrifuge tubes and kept at $-20{ }^{\circ} \mathrm{C}$ until experimentation.

Estimation of VD in blood serum, epididymal luminal fluid and sperm cytosol. While $1,25(\mathrm{OH}) 2 \mathrm{D} 3$ is the metabolically active form of vitamin-D, the concentration of its precursor, $25(\mathrm{OH}) \mathrm{D} 3$, is considered to be the best indicator of Vitamin-D status in animals 
S. Chattaraj et al.: Vitamin D as an important constituent of epididymal luminal micro-environment for maturation of spermatozoa in Large White Yorkshire Boar

(ARNOLD et al.,, 2015). These were measured in the serum and ELF, and SCF from different segments of the right epididymis following the protocol described by HOLICK (2009) and BIKLE (2010) using 25-HydroryVitamin D3 enzyme-linked immunosorbent assay (ELISA), Kit (CALBIOTEC, USA). The concentrations of each of the 30 samples were then intercepted from the standard curve against their optical density (OD) values.

Semi-quantitative analysis of VDR gene expression in liver, testis, epididymal tissues and spermatozoa by RT-PCR and gel electrophoresis. The total RNA was isolated from different tissues and cell samples using Trizol ${ }^{\circledR}$ reagent (Invitrogen origin) as developed by CHOMCZYNSKI and SACHHI (1987). Then, first strand cDNA was synthesized from DNase I-treated RNA Verso cDNA kit (Thermo Fisher Scientific, USA). Then a semi-quantitative PCR was performed to quantify and study the expression of the VDR gene, using cDNA as the template and gene-specific primers designed (Table 1). The densitometric value of each PCR product was measured using MacBiophotonics Image software. Relative expression of VDR mRNA was normalized using the $\beta$-actin (ACTB) gene as an internal control for each sample.

Table 1. Gene Transcripts, primer sequences and resulting fragment size

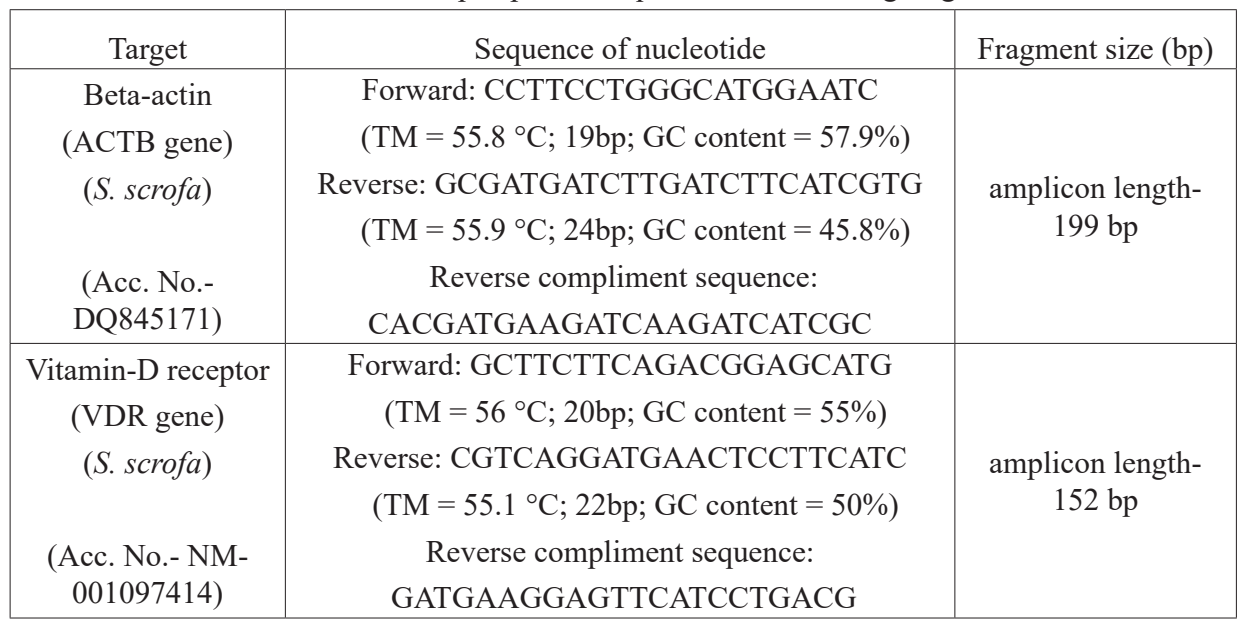

The reaction was carried out with the PCR mixture of VDR and $\beta$-actin (ACTB) genes, using forward and reverse primers for VDR and $\beta$-actin, in a thermal cycler (BioRad, USA). For the amplification of VDR and $\beta$-actin (ACTB) gene fragments the following thermal cycle (Fig. 1) was used: the PCR reaction was initiated by hot start at $95^{\circ} \mathrm{C}$ for $3 \mathrm{~min}$ for initial denaturation, followed by 30 cycles of reaction at $95^{\circ} \mathrm{C}$ for 30 $\mathrm{s}$ for denaturation, $55^{\circ} \mathrm{C}$ for $30 \mathrm{~s}$ for annealing of VDR and $\beta$-actin and then at $72{ }^{\circ} \mathrm{C}$ for $12 \mathrm{~s}$. Finally it was extended at $72{ }^{\circ} \mathrm{C}$ for $10 \mathrm{~min}$ (Fig. 1). The PCR products were kept at $-20{ }^{\circ} \mathrm{C}$ for study of the expression. 
S. Chattaraj et al.: Vitamin D as an important constituent of epididymal luminal micro-environment for maturation of spermatozoa in Large White Yorkshire Boar

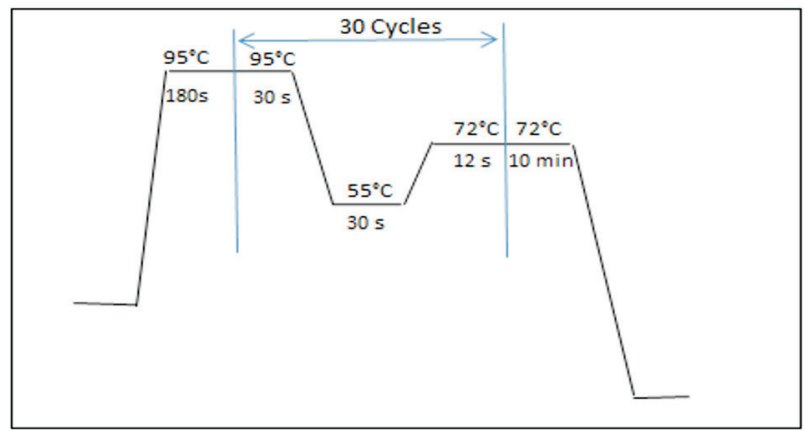

Fig. 1. Protocol for thermal cycle for reaction of the PCR mixture of VDR and $\beta$-actin (ACTB) genes

The PCR products were analysed on a $2 \%$ agarose gel. The gel was examined by gel documentation system and the densitometric value of each PCR product was measured using Mac Biophotonics Image software.

Statistical analysis. All of the data were analysed using SPSS (Windows Ver. 23) software package (Statistical Package for Social Science). Descriptive statistics and General Linear Model (GLM) were used to analyse the data. Pearson's bivariate correlation method was used to find the correlation coefficient. The means were compared using Duncan Multiple Range tests (DUNCAN, 1995). The prediction equations were developed using curve fit regression equations.

\section{Results}

Evaluation of spermatozoan motility from three regions of the epididymis. In the case of boars, motility is an important indication of spermatozoan maturation in the epididymis (DACHEUX et al., 1979). Therefore, a subjective evaluation of the spermatozoan motility of the samples retrieved from the three different regions of the left epididymis $(n=30)$ revealed that spermatozoan motility was highest in the cauda segment $(90.95 \pm$ $0.80)$ followed by the corpus $(15.82 \pm 0.24)$ and motility was absent in the caput region (Table 2; Fig. 2). Analysis of variance (ANOVA; Duncan test) revealed that spermatozoan motility in the regions had significant variation $(\mathrm{P}<0.05)$ (Table 2$)$.

$V D$ levels in serum, ELF and SCF from the right epididymal regions. The mean $\pm \mathrm{SE}$ concentration of VD in serum is presented in Table 2 and Fig. 3. ANOVA revealed that there were significant differences $(\mathrm{P}<0.05)$ in the VD concentrations in the ELF and SCF from each of the three segments of the epididymis, however, corpus ELF and caput SCF, and cauda ELF and SCF exhibited no significant differences. Serum VD concentrations also had significant relative differences $(\mathrm{P}<0.05)$ except to cauda ELF concentrations of VD (Table 2). 
S. Chattaraj et al.: Vitamin D as an important constituent of epididymal luminal micro-environment for maturation of spermatozoa in Large White Yorkshire Boar

Table 2. Spermatozoan motility (\%) in ELF; concentrations of Vitamin-D in serum, ELF and SCF from different regions of the LWY boar epididymis $(n=30)$

\begin{tabular}{|c|c|c|c|c|c|c|c|}
\hline \multirow[b]{2}{*}{ Parameters } & \multirow{2}{*}{$\begin{array}{l}\text { Blood serum } \\
(\text { Mean } \pm \text { SE })\end{array}$} & \multicolumn{3}{|c|}{$\begin{array}{l}\text { Epididymal luminal fluid (ELF) } \\
(\text { Mean } \pm \text { SE) }\end{array}$} & \multicolumn{3}{|c|}{$\begin{array}{c}\text { Sperm cytosolic fluid (SCF) } \\
(\text { Mean } \pm \text { SE })\end{array}$} \\
\hline & & Caput & Corpus & Cauda & Caput & Corpus & Cauda \\
\hline $\begin{array}{l}\text { Motility } \\
(\%)\end{array}$ & - & 0 & $\begin{array}{l}15.82 \\
\pm 0.24^{\mathrm{a}}\end{array}$ & $\begin{array}{l}90.95 \\
\pm 0.80^{\mathrm{b}}\end{array}$ & - & - & - \\
\hline $\begin{array}{l}\text { Vitamin-D } \\
(\mathrm{ng} / \mathrm{mL})\end{array}$ & $\begin{array}{l}45.08 \\
\pm 2.14^{\mathrm{b}}\end{array}$ & $\begin{array}{l}20.47 \\
\pm 0.98^{\mathrm{e}}\end{array}$ & $\begin{array}{l}32.67 \\
\pm 0.97^{\mathrm{d}}\end{array}$ & $\begin{array}{l}47.70 \\
\pm 1.73^{\mathrm{ab}}\end{array}$ & $\begin{array}{l}28.65 \\
\pm 1.59^{\mathrm{d}}\end{array}$ & $\begin{array}{l}39.74 \\
\pm 1.60^{c}\end{array}$ & $\begin{array}{l}51.38 \\
\pm 1.31^{\mathrm{a}}\end{array}$ \\
\hline
\end{tabular}

a-f - The same superscripts in a given row indicate non-significant differences within the same step (ANOVADuncan test at $\mathrm{P}<0.05$ ).

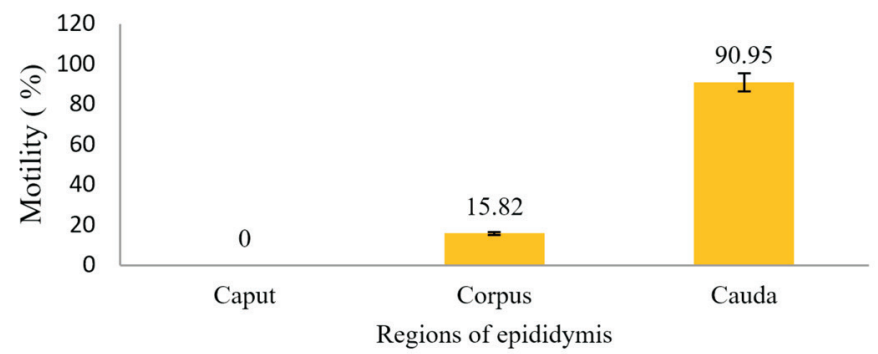

Fig. 2. Spermatozoan motility (\%) from different segments of the LWY boar epididymis. Each bar represents Mean $\pm \mathrm{SE}(\mathrm{n}=30)$, significant at $\mathrm{P}<0.05$.

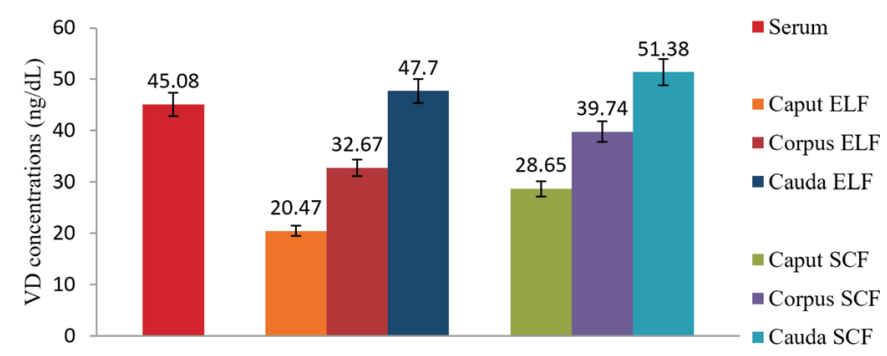

Fig. 3. Concentrations of VD in serum, and ELF, SCF from different segments of the LWY boar epididymis. Each bar represents Mean $\pm \mathrm{SE}(\mathrm{n}=30)$, significant at $\mathrm{P}<0.05$.

Serum VD concentration exhibited a positive relationship with that of ELF and SCF from the caput corpus and cauda. It was also positively correlated with spermatozoan motility from the corpus $(\mathrm{r}=0.819)$ and cauda $(\mathrm{r}=0.961)$, and this was highly significant $(\mathrm{P}<0.01)$ (Table 3). 
S. Chattaraj et al:: Vitamin D as an important constituent of epididymal luminal micro-environment for maturation of spermatozoa in Large White Yorkshire Boar

In ELF, sperm motility in the corpus $(r=0.709)$ and cauda $(r=0.889)$ had a positive correlation with VD concentrations in the respective segments (Table 3). Further, VD concentrations between the segments of the epididymis had a positive relationship. VD concentrations in the ELF from the three segments exhibited a positive relationship with the SCF from the respective epididymal segment (Table 3). These relationships were highly significant $(\mathrm{P}<0.01)$.

In SCF, VD concentrations had a positive correlation with sperm motility from the corpus and cauda $(r=0.736)$ and $(r=0.959)$ (Table 3$)$ and these relationships were also highly significant $(\mathrm{P}<0.01)$.

Table 3. Correlation coefficient (r) of VD concentrations in serum, segments of ELF \& SCF and with sperm motility in the corpus (Cor) and cauda (Cau) epididymis

\begin{tabular}{|l|c|c|c|c|c|c|c|c|c|}
\hline & $\begin{array}{c}\text { Serum } \\
\text { VD }\end{array}$ & $\begin{array}{c}\text { ELF } \\
\text { Cap } \\
\text { VD }\end{array}$ & $\begin{array}{c}\text { ELF } \\
\text { Cor } \\
\text { VD }\end{array}$ & $\begin{array}{c}\text { ELF } \\
\text { Cau } \\
\text { VD }\end{array}$ & $\begin{array}{c}\text { SCF } \\
\text { Cap } \\
\text { VD }\end{array}$ & $\begin{array}{c}\text { SCF } \\
\text { Cor } \\
\text { VD }\end{array}$ & $\begin{array}{c}\text { SCF } \\
\text { Cau } \\
\text { VD }\end{array}$ & $\begin{array}{c}\text { ELF } \\
\text { Cor } \\
\text { Motility }\end{array}$ & $\begin{array}{c}\text { ELF } \\
\text { Cau } \\
\text { Motility }\end{array}$ \\
\hline Serum VD & 1 & & & & & & & & \\
\hline ELF Cap VD & $0.982^{* *}$ & 1 & & & & & & & \\
\hline ELF Cor VD & $0.960^{* *}$ & $0.933^{* *}$ & 1 & & & & & & \\
\hline ELF Cau VD & $0.951^{* *}$ & $0.926^{* *}$ & $0.982^{* *}$ & 1 & & & & & \\
\hline SCF Cap VD & $0.971^{* *}$ & $0.958^{* *}$ & $0.912^{* *}$ & $0.887^{* *}$ & 1 & & & & \\
\hline SCF Cor VD & $0.946^{* *}$ & $0.902^{* *}$ & $0.953^{* *}$ & $0.925^{* *}$ & $0.941^{* *}$ & 1 & & & \\
\hline SCF Cau VD & $0.980^{* *}$ & $0.965^{* *}$ & $0.938^{* *}$ & $0.932^{* *}$ & $0.968^{* *}$ & $0.950^{* *}$ & 1 & & \\
\hline ELF Cor Motility & $0.819^{* *}$ & $0.838^{* *}$ & $0.709^{* *}$ & $0.669^{* *}$ & $0.900^{* *}$ & $0.736^{* *}$ & $0.834^{* *}$ & 1 & \\
\hline ELF Cau Motility & $0.961^{* *}$ & $0.949^{* *}$ & $0.900^{* * *}$ & $0.889^{* *}$ & $0.961^{* *}$ & $0.940^{* *}$ & $0.959^{* *}$ & $0.812^{* *}$ & 1 \\
\hline
\end{tabular}

** Correlation is significant at $0.01 \%$ level (2-tailed)

\section{$V D R$ gene expression in three epididymal segments and caudal sperm}

Total RNA isolation and quantification. The yield of total RNA isolated from the tissues and cells was good and of high quality. The OD 260 : OD 280 values of each sample were between $1.8-1.9$ and the concentrations varied between $(0.8-1) \mu \mathrm{g} / \mu \mathrm{l}$ when measured using a nano-drop2000 instrument (Thermo Scientific, USA).

DNA synthesis and its confirmation. The integrity of first strand cDNA synthesized from DNase-I treated RNA was analysed by the already published primer ACTB (Beta actin) gene amplification, in 2.0\% agarose gel. A single band of 199 bp was visualized in each of the tissues and sperm (Fig. 4). 
S. Chattaraj et al.: Vitamin D as an important constituent of epididymal luminal micro-environment for maturation of spermatozoa in Large White Yorkshire Boar

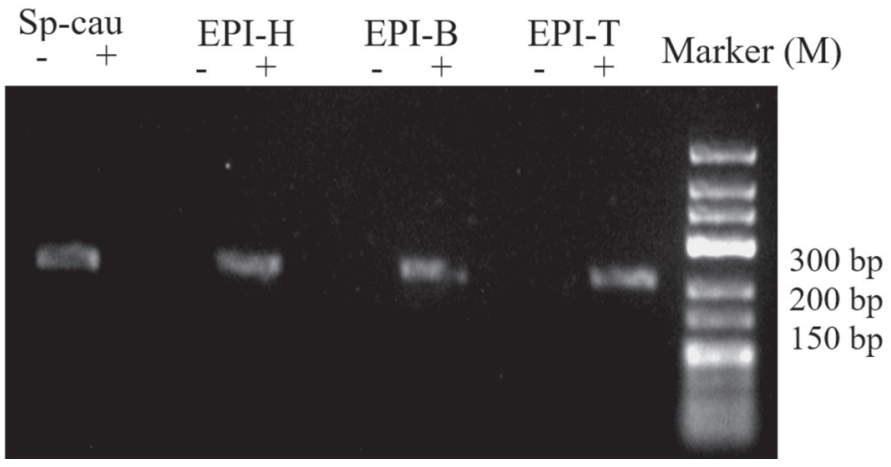

Fig. 4. Agarose gel electrophoresis for PCR amplification of Beta-actin gene in Cauda sperm (Spcau), Caput (Epi-H), Corpus (Epi-B), Cauda (Epi-T). Lane 1 to 4: 199 bp PCR product: Lane M: 500 bp DNA ladder.

Amplification of the VDR gene. Following gradient PCR, the products were run in $2 \%$ agarose gel electrophoresis to check the amplicon length. As expected, a single and specific band of 152 bp for the VDR gene was amplified from the cDNA (Fig. 5).

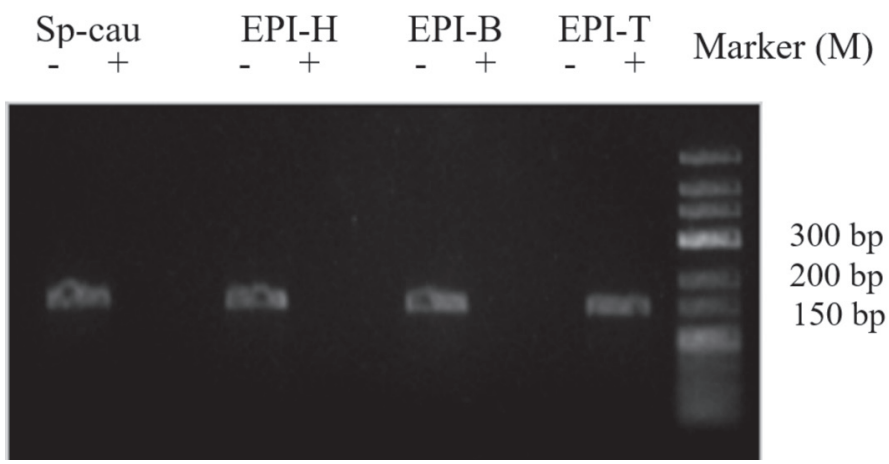

Fig. 5. Agarose gel electrophoresis for PCR amplification of VDR gene in Cauda sperm (Sp-cau), Caput (Epi-H), Corpus (Epi-B), Cauda (Epi-T). Lane 1 to 4: 152 bp PCR product; Lane M : 500 bp DNA ladder.

Gel documentation. The densitometric value was measured using Mac Biophotonics Image software and the relative density of VDR with respect to ACBT is presented in Table 4 and Fig. 6. Semi-quantitative RT-PCR revealed that VDR transcripts were found in similar amounts in all the sections isolated from LWY boars. However, there was no significant $(\mathrm{P}<0.05)$ measurable change in the transcript abundance with respect to the different sections. 
S. Chattaraj et al.: Vitamin D as an important constituent of epididymal luminal micro-environment for maturation of spermatozoa in Large White Yorkshire Boar

Table 4. Densitometric values of VDR and ACBT genes in all tissues and sperm

\begin{tabular}{|l|c|c|c|c|}
\hline & $\begin{array}{c}\text { Cauda- sperm } \\
(\text { Sp-cau })\end{array}$ & $\begin{array}{c}\text { Caput } \\
(\text { Epi-H })\end{array}$ & $\begin{array}{c}\text { Corpus } \\
(\text { Epi-B })\end{array}$ & $\begin{array}{c}\text { Cauda } \\
(\text { Epi-T })\end{array}$ \\
\hline $\begin{array}{l}\text { Vitamin-D receptor } \\
(\text { VDR })\end{array}$ & 43.19 & 57.96 & 59.53 & 66.72 \\
\hline $\begin{array}{l}\text { Beta actin } \\
(\text { ACTB })\end{array}$ & 104.42 & 117.89 & 111.98 & 113.04 \\
\hline VDR/ACTB & $0.41^{\mathrm{a}}$ & $0.49^{\mathrm{a}}$ & $0.53^{\mathrm{a}}$ & $0.59^{\mathrm{a}}$ \\
\hline
\end{tabular}

${ }^{a}$ values had non-significant differences (ANOVA-Duncan test at $\mathrm{P}<0.05$ ).

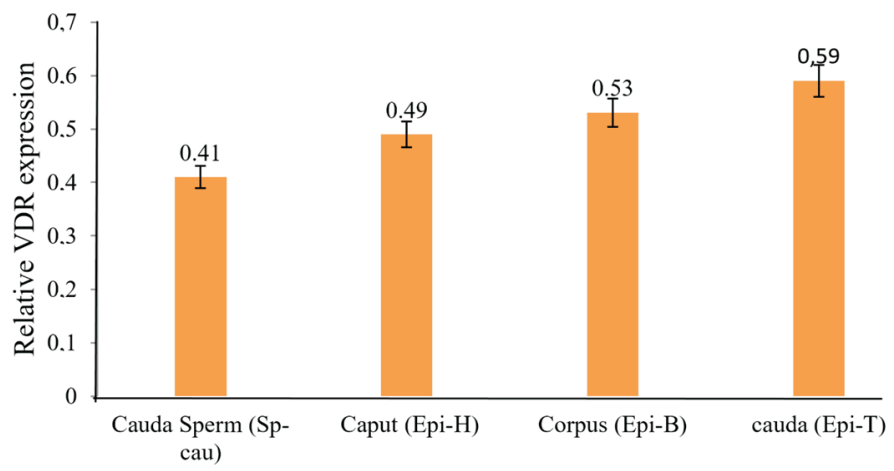

Tissues/ Cells

Fig. 6. Relative VDR expression of spermatozoa from cauda epididymis and epididymal segments- caput, corpus and cauda. Values had non-significant differences (ANOVA-Duncan test at $\mathrm{P}<0.05$ ).

\section{Discussion}

In the present study, sperm motility in LWY boars increased gradually as it travelled through the epididymis, except in the caput epididymis where spermatozoa did not move at all. This could be compared to the findings of many researchers in different species, including bucks (RANJAN, 2012) and bulls (VIJAYRAGHAVAN et al., 1996). In boars, the observations of OYEYEMI and UBIOGORO (2005) corroborated with the present study.

The findings suggest that epididymal factors are responsible for the initiation and maintenance of sperm motility in boars, similar to the report on bovines by HOSKINS et al. (1978) and in the case of humans by NELSON (1985). The development or gradual increase in the motility of spermatozoa in the epididymis is associated with an increase in intra-sperm levels of cyclic AMP (cAMP), which is an essential second messenger in sperm physiology (YANAGIMACHI, 1994). The cAMP was synthesized by a soluble adenylyl cyclase (sAC) (LITVIN et al.,, 2003). 
S. Chattaraj et al.: Vitamin D as an important constituent of epididymal luminal micro-environment for maturation of spermatozoa in Large White Yorkshire Boar

However, it has been postulated that the changing levels of cAMP are controlled either directly or indirectly by the changing levels of polypeptides, ions, lipids, vitamins, enzymes and hormones, both in the cases of intra-sperm and within ELF throughout the epididymis. VD, then is one of the biomolecules that play a pivotal role in influencing sperm motility, exerting indirect control on cAMP levels of spermatozoa (LINDEMANN and KANOUS, 1989).

The serum concentrations of VD as obtained remained within the range of data reported by ARNOLD et al. (2015) in boars. Further, a positive correlation between sperm motility in the epididymis and VD concentrations in serum was observed, which corroborated with the findings of JENSEN et al. (2011). He observed a lower proportion of motile, progressively motile, and morphologically normal spermatozoa in men with vitamin D deficiency $(<10 \mathrm{ng} / \mathrm{mL}$ of serum VD) in comparison with men with sufficient vitamin D status in serum $(>30 \mathrm{ng} / \mathrm{mL})$.

The concentrations of VD in ELF and SCF obtained from the caput, corpus and cauda increased during transit through the epididymis. In boars, this increase in VD concentration in ELF and SCF could not be corroborated well due to the lack of reported data. The increase in sperm VD was probably due to the local production of VD since 25(OH) D3-1, $\alpha$-hydroxylase was detected in the sperm (AQUILA et al., 2009).

A positive relationship between sperm motility and VD concentrations in ELF and SCF from different fractions of the epididymis was also exhibited in the present study. Thus an increasing concentration of VD and progressive development of sperm motility from the caput to the cauda is indicative of the fact that it might be responsible for the increase in sperm motility from the caput to the cauda in the epididymis.

The exact mechanism of VD in the initiation of sperm motility however is not very clear. It is postulated that VD exerts its influence through binding to a Vitamin-D receptor (VDR). In spermatozoa, VD exerts its role through the VDR, located predominantly on the head/nucleus and mid-piece in human sperm (AQUILA et al., 2008). The VDR elicits a rapid increase in intracellular $\mathrm{Ca}^{2+}$ concentration through inositol trisphosphate (IP3) mediated $\mathrm{Ca}^{2+}$ release from an intracellular IP3 receptor gated calcium store in the neck of human spermatozoa (JENSEN and DISSING, 2012).

Moreover, VD is an important factor in oestrogen biosynthesis in both female and male gonads (KINUTA et al., 2000) as it regulates aromatase (CYP19A1) in human testes (BULUN et al., 1993). VD thus has been found to influence the resorption, regulation and $\mathrm{pH}$ of epididymal fluid (JOHNSON et al., 1996). Further, VD in human sperm cells seems to modulate cholesterol efflux, resulting in destabilization of sperm membrane and increased fluidity. This again stimulates the opening of the L-calcium channels and the entry of calcium (FORESTA et al., 2011). These in turn activate soluble adenyl cyclise (sAC) to produce cAMP from ATP. The increased cAMP further activates protein kinase 
S. Chattaraj et al.: Vitamin D as an important constituent of epididymal luminal micro-environment for maturation of spermatozoa in Large White Yorkshire Boar

$\mathrm{A}(\mathrm{PKA})$ and $\mathrm{C}(\mathrm{PKC})$, increasing tyrosine and threonine phosphorylation of proteins (AQUILA et al.,, 2009).

Hence, the present observation suggests that VD plays a vital role in the regulation of many biomolecules, and maintains homeostasis through complex mechanism(s) in the epididymal microenvironment, which is essential for sperm maturation.

\section{Conclusions}

On the basis of the above investigation, it may be concluded that the mammalian epididymis and its ever changing micro-environmental phenomena, promote unique modifications of the male gamete that are necessary for the spermatozoa to become fertilizing-competent cells. Besides, the estimation of vitamin D3 from the ELF, SCF, as well as VDR gene expressions in the reproductive tissues/cells, is the first of its kind in boars. Furthermore, from the clinical point of view, the present findings about spermatozoa maturation may pave the way for the further development of specific marker(s) that will assist in both the prediction and early diagnosis of male infertility. It will also help in improving treatment modalities of male infertility, since epididymal dysfunctions are related to cases of idiopathic male infertility.

\section{Acknowledgements}

We thank all the authors for their valuable contribution. We are also thankful to the entire faculty and all advisors for their contribution to the completion of the research work. The research work was performed with our own funding from the department.

\section{References}

ANONYMOUS (1997): Laboratory manual for the examinations of human semen and sperm cervical mucus interaction (3e). World Health Organization - Cambridge, The Press Syndicate of the University of Cambridge.

AQUILA, S., C. GUIDO, I. PERROTTA, S. TRIPEPI, A. NASTRO, S. ANDO (2008): Human sperm anatomy: Ultrastructural localization of 1alpha,25-dihydroxyvitamin D receptor and its possible role in the human male gamete. J. Anat. 213, 555-64.

DOI: $10.1111 /$ j.1469-7580.2008.00975.x

AQUilA, S., C. GUIDO, E. MIDDEA, I. PERROTTA, R. BRUNO, M. PELLEGRINO,S. ANDÒ (2009): Human male gamete endocrinology: 1alpha, 25-dihydroxyvitamin D3 $(1,25(\mathrm{OH}) 2 \mathrm{D} 3)$ regulates different aspects of human sperm biology and metabolism. Reprod. Biol. Endocrinol. 7, 1-13.

DOI: $10.1186 / 1477-7827-7-140$

ARNOLD, J., D. M. MADSON, S. M. ENSLEY (2015): Survey of serum vitamin D status across stages of swine production and evaluation of supplemental bulk vitamin D premixes used in swine diets. J. Swine Health Prod. 23, 28-34. 
S. Chattaraj et al.: Vitamin D as an important constituent of epididymal luminal micro-environment for maturation of spermatozoa in Large White Yorkshire Boar

BIKLE, D. D. (2010): Vitamin-D and the skin. J. Bone Miner. Metab. 28, 117-30.

DOI: $10.1007 / \mathrm{s} 00774-009-0153-8$

BULUN, S. E., I. M. ROSENTHAL, A. M. BRODIE (1993): Use of tissue specific promoters in the regulation of aromatase cytochrome P450 gene expression in human testicular and ovarian sex cord tumors, as well as in normal fetal and adult gonads. J. Clin. Endocr. Metabol. 77, 1616-1621.

DOI: $10.1210 /$ jcem.77.6.8263150

CHOMCZYNSKI, P., N. SACHHI (1987): Single Step Method of RNA isolation by Acid Guanidinium Thiocynate-Phenol-Chloroform Extraction. Anal. Biochem. 162, 156-159.

DOI: $10.1016 / 0003-2697(87) 90021-2$

CORNWALL, G. A. (2009): New insights into epididymal biology and function. Human Reprod. Update 15, 213-227.

DOI: $10.1093 /$ humupd/dmn055

DACHEUX, J. L., T. O'SHEA, M. PAQUIGNON (1979): Effects of osmolality, bicarbonate and buffer on the metabolism and motility of testicular, epididymal and ejaculated spermatozoa of boars. J. Reprod. Fertil. 55, 287-296.

DOI: $10.1530 /$ jrf.0.0550287

DACHEUX, J. L., M. PAQUIGNON (1980): Relations between the fertilizing ability, motility and metabolism of epididymal spermatozoa. Reprod. Nutr. Dev. 20, 1085-1099.

DOI: $10.1051 /$ rnd:19800617

DACHEUX, J. L., F. DACHEUX (2013): New insights into epididymal function in relation to sperm maturation. Reprod. 147, R27-42.

DOI: $10.1530 /$ rep-13-0420

DUNCAN, D. B.(1995): Multiple range and multiple F test. Biometrics 11, 1-42.

DOI: $10.2307 / 3001478$

FORESTA, C., G. STRAPAZZON, L. DE TONI (2011): Bone mineral density and testicular failure: evidence for a role of vitamin D 25-(OH)lase in human testis. J. Clin. Endocr. Metab. 96, E646-52.

DOI: $10.1210 /$ jc. $2010-1628$

FRENETTE, G., C. LESSARD, R. SULLIVAN (2002): Selected proteins of "Prostasome-Like Particles" from epididymal cauda fluid are transferred to epididymal caput spermatozoa in bull. Biol. Reprod. 67, 308-313.

DOI: $10.1095 /$ biolreprod67.1.308

HOLICK, M. F.(2009): Vitamin D status: measurement, interpretation and clinical application. Ann. Epidemoil. 19, 73-78.

DOI: 10.1016/j.annepidem.2007.12.001

HORI, T., T. ATAGO, M. KOBAYASHI E. KAWAKAMI (2015): Influence of different methods of collection from the canine epididymides on post-thaw caudal epididymal sperm quality. J. Vet. Med. Sci. 77, 625-630.

DOI: $10.1292 /$ jvms. $14-0421$ 
S. Chattaraj et al.: Vitamin D as an important constituent of epididymal luminal micro-environment for maturation of spermatozoa in Large White Yorkshire Boar

HOSKINS, D. D., H. H. BRANDT, T. S. ACOTT (1978): Initiation of sperm motility in the mammalian epididymis. Fedn. Proc. 37, 2534-2542.

PMid:211050

JENSEN, B. M., P. J. BJERRUM, T. E. JESSEN, J. E. NIELSEN, U. N. JOENSEN, I. A. OLESEN, J. H. PETERSEN, A. JUUL, S. DISSING, N. JORGENSEN (2011): Vitamin D is positively associated with sperm motility and increases intracellular calcium in human spermatozoa. Human Reprod. 26, 1307-1317.

DOI: $10.1093 /$ humrep/der059

JENSEN, B. M., S. DISSING (2012): Non-genomic effects of Vitamin D in human spermatozoa. Steroids 77, 903-909.

DOI: $10.1016 /$ j.steroids.2012.02.020

JOHNSON, J. A., J. P. GRANDE, P. C. ROCHE, R. KUMAR(1996): Immunohistochemical detection and distribution of the 1,25-dihydroxyvitamin $\mathrm{D} 3$ receptor in rat reproductive tissues. Histochemistry and Cell Biology. 105, 7-15.

DOI: $10.1007 / \mathrm{BF} 01450873$

KINUTA, K., H. TANAKA, T. MORIWAKE, K. AYA, S. KATO, Y. SEINO (2000): Vitamin D is an important factor is an important factor is estrogen biosynthesis of both female and male gonads. Endrocrinol. 141, 1317-1324.

DOI: $10.1210 /$ endo.141.4.7403

LINDEMANN, C. B., K. S. KANOUS (1989): Regulation of mammalian sperm motility. Arch. Androl. 23, 1-22.

DOI: $10.3109 / 01485018908986783$

LITVIN, T. N., M. KAMENETSKY, A. ZARIFYAN, J. BUCK, L. R. LEVIN (2003): Kinetic properties of "soluble" adenylyl cyclase. Synergism between calcium and bicarbonate. J. Biol. Chem. 278,15922-15926.

DOI: $10.1074 /$ jbc.m212475200

NELSON, L. (1985): Biology of fertilization. (Metz, C. B., A. Monroy, Eds.) Vol. II. Academic Press, London, New York, pp. 215-234.

DOI: $10.1016 /$ B978-0-12-492602-8.50012-7

OYEYEMI, M.O., O. UBIOGORO (2005): Spermiogram and morphological characteristics in testicular and epididymal spermatozoa of large white boar in Nigeri. Int. J. Morphol. 23, 235239.

DOI: $10.4067 / \mathrm{s} 0717-95022005000300008$

RANJAN, A.(2012): Topographical distribution of calcium, cholesterol, estrogen, and vitamin-D3 in the Jamunapari buck (Capra hircus) excurrent duct and their relationship with spermatozoan motility. M.V.Sc. Thesis, W.B.A.F.S. West Bengal, India.

ROBAIRE, B., B. T. HINTON, M. C. ORGEBIN-CRIST, (2006): The epididymis. In: Physiology of Reproduction. (JN, K., Ed.). New York: Elsevier. pp. 1071-1148.

DOI: $10.1016 / \mathrm{B} 978-012515400-0 / 50027-0$

Vet. arhiv 89 (2), 169-182, 2019 
S. Chattaraj et al.: Vitamin D as an important constituent of epididymal luminal micro-environment for maturation of spermatozoa in Large White Yorkshire Boar

SULLIVAN, R. (2004): Male fertility markers, myth or reality. Ani. Reprod. Sci. 82-83, 341-347.

DOI: 10.1016/j.anireprosci.2004.05.007

VIJAYARAGHAVAN, S., D. T. STEPHENS, K. TRAUTMAN, G. D. SMITH, B. KHATRA, E. F. DA CRUZ E SILVA, P. GREENGARD (1996): Sperm motility development in the epididymis is associated with decreased glycogen synthase kinase- 3 and protein phosphatase 1 activity. Biol. Reprod. 54, 709-718.

DOI: $10.1095 /$ biolreprod54.3.709

WALES, R. G., J. C. WALLACE, I. G. WHITE (1966): Composition of bull epididymal and testicular fluid. J. Reprod. Fert. 12, 139-144.

DOI: $10.1530 /$ jrf.0.0120139

WERNERSSON, R., M. H. SCHIERUP, F. G. JØRGENSEN, J. GORODKIN, F. PANITZ, H. H. STAERFELDT, O. F. CHRISTENSEN, T. MAILUND, H. HORNSHØJ, A. KLEIN (2005): Pigs in sequence space: a $0.66 \times$ coverage pig genome survey based on shotgun sequencing. BMC Genomics 6, 70.

DOI: $10.1186 / 1471-2164-6-70$

YANAGIMACHI, R. (1994): Mammalian fertilization In: The Physiology of Reproduction. (Knobile E., J. D. Neill, Eds.) New York, Raven. pp. 189-317.

Received: 2 January 2018

Accepted: 15 December 2018

\section{CHATTARAJ, S., S. BASU, K. RAY, D. S. PAL: Vitamin D kao sastojak luminalne tekućine pasjemenika važan je za sazrijevanje spermija u nerasta pasmine veliki bijeli jorkšir. Vet. arhiv 89, 169-182, 2019. \\ SAŽETAK}

Poznato je da vitamin D (VD) usklađuje reproduktivne procese ekspresijom VDR-a u reproduktivnom sustavu mužjaka. Kako bismo razumjeli njegov utjecaj na pokretanje spermija u pasjemeniku, izmjerena je koncentracija vitamina D u serumu, luminalnoj tekućini pasjemenika (ELF) i citosolnoj tekućini spermija $(\mathrm{SCF})$ uzetoj iz glave, tijela i repa pasjemenika nerasta pasmine veliki bijeli jorkšir $(\mathrm{n}=30)$ dobi 3 - 4 godine. Promatran je odnos koncentracije vitamina D i pokretljivosti spermija u dijelovima pasjemenika. Uočeno je progresivno povećanje pokretljivosti spermija od glave (gdje su mirovali) preko tijela do repa pasjemenika. Razine vitamina $\mathrm{D}$ u serumu pozitivno su korelirale s pokretljivošću spermija iz tijela $(\mathrm{r}=0,819)$ i repa $(\mathrm{r}=$ $0,961$ ), što je bilo statistički znakovito ( $\mathrm{P}<0,01)$. Opet, razine vitamina $\mathrm{D}$ u ELF-u i SCF-u pokazale su pozitivnu korelaciju s pokretljivošću spermija u tijelu i repu odgovarajućih dijelova pasjemenika, što je bilo statistički znakovito $(\mathrm{P}<0,01)$. Polukvantitativni RT-PCR pokazao je ekspresiju gena VDR u dijelovima pasjemenika i spermi iz repa pasjemenika nerasta pasmine veliki bijeli jorkšir. Transkripcija VDR-a (koji nije znakovit, $\mathrm{P}>0,05)$ iz dijelova od glave do repa pasjemenika porasla je istodobno s porastom koncentracije vitamina $\mathrm{D}$ što upućuje na utjecaj vitamina $D$ na početak pokretljivosti spermija u odvodnim kanalima. Razine vitamina D u serumu mogle bi utrti put razvoju specifičnih markera koji bi mogli pomoći u ranom dijagnosticiranju idiopatske neplodnosti u mužjaka uzrokovane disfunkcijom pasjemenika zbog manjka vitamina $\mathrm{D}$. To može klinički pomoći u unapređenju modaliteta liječenja idiopatske neplodnosti u mužjaka.

Ključne riječi: Vitamin D; luminalna tekućina pasjemenika; citosolna tekućina spermija; pokretljivost spermija; polukvantitativni RT-PCR; gen VDR 